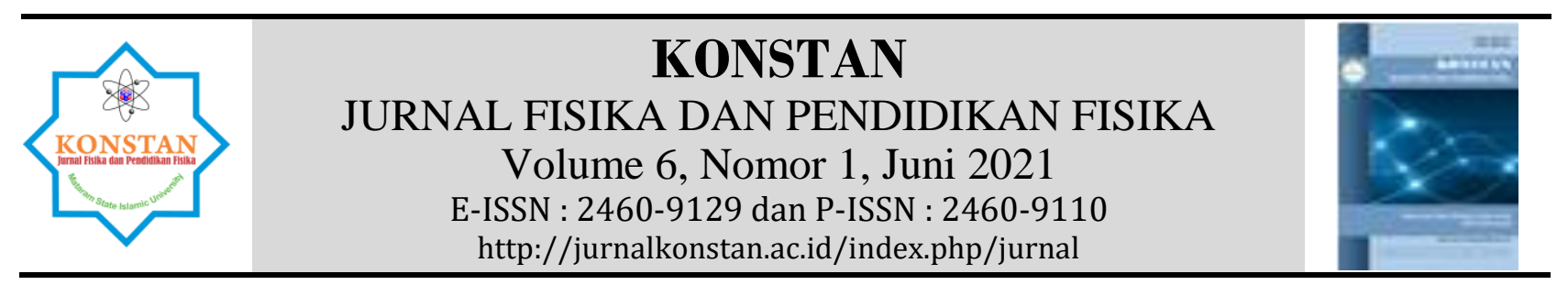

\title{
Pengembangan Perangkat Pembelajaran dengan Model Reciprocal Teaching untuk Meningkatkan Hasil Belajar Fisika Peserta Didik
}

\author{
L. Muh. Agri Yusna ${ }^{1, *)}$, Ahmad Harjono ${ }^{1}$, Syahrial Ayub ${ }^{1}$, Wahyudi ${ }^{1}$ \\ ${ }^{1)}$ Program Studi Pendidikan Fisika FKIP Universitas Mataram, Jalan Majapabit No. 62, kota Mataram, \\ Nusa Tenggara Barat, Indonesia
}

*E-mail korespondensi: agriyusna01@gmail.com

\begin{abstract}
Info Artikel: Abstract
Dikirim:

14 April 2021

Revisi:

17 Mei 2021

Diterima:

27 Mei 2021

Kata Kunci:

Penelitian ini bertujuan untuk mengetahui kelayakan produk perangkat pembelajaran dengan model reciprocal teaching untuk meningkatkan hasil belajar fisika peserta didik. Penelitian ini menggunakan metode penelitian Research and Development (R\&D) dengan model penelitian 4D Models yang terdiri dari tahap pendefinisian (Define), perancangan (Desain), pengembangan (Develop), dan penyebaran (Disseminate). Kelayakan perangkat pembelajaran yang dikembangkan dilihat dari hasil rata-rata perhitungan skor penilaian enam ahli yang dihitung dengan validitas dan reliabilitas perangkat.

Pengembangan

Perangkat

Pembelajaran,

Reciprocal

Teaching,

Hasil Belajar. Selanjutnya dilakukan penyebaran angket respon pada mahasiswa S1 pendidikan fisika FKIP, Universitas Mataram. Hasil penelitian berdasarkan penilaian ahli menunjukkan bahwa hasil pengembangan perangkat pembelajaran memiliki nilai kelayakan dengan kriteria cukup valid dan reliabel pada Silabus, RPP, Materi Ajar, LKPD dan instrumen tes yang dikembangkan. Hasil respon mahasiswa dan peserta didik menunjukkan respon sangat baik sehingga, dapat disimpulkan perangkat pembelajaran dengan model reciprocal teaching layak dilanjutkan ke tahap uji coba dalam proses pembelajaran untuk meningkatkan hasil belajar fisika peserta didik.
\end{abstract}

(C) 2021 Universitas Islam Negeri Mataram

\section{PENDAHULUAN}

Pembelajaran merupakan interaksi yang terjadi antara guru dan peserta didik yang mana pendidik memberikan informasi atau pengetahuan baru pada peserta didik untuk menambah pengalaman belajar. Guru merupakan bagian terpenting dari sebuah pembelajaran, karena guru bertanggung jawab penuh dalam memberikan informasi ataupun pengetahuan baru bagi peserta didik. Guru harus memberikan model pembelajaran yang mampu meningkatkan semangat belajar serta menjadikan peserta didik menjadi lebih aktif selama pembelajaran. Pembelajaran merupakan proses aktif yang dihasilkan melalui keterlibatan aktif individu dalam merefleksikan pengalaman dan tindakan yang ia praktikkan di lingkungan tertentu [1]. Begitu pula dalam melaksanakan pembelajaran fisika, pembelajaran fisika merupakan pembelajaran interaktif, sehingga guru harus mampu menciptakan suasana belajar yang komunikatif. Pembelajaran sebaiknya berpusat kepada peserta didik agar peserta didik mendapatkan pengalaman belajar yang lebih baik dan sesuai dengan kurikulum 2013.

Salah satu tujuan pembelajaran fisika yang tertuang dalam kurikulum 2013 adalah menguasai konsep dan prinsip serta mempunyai keterampilan mengembangkan pengetahuan dan sikap percaya diri sebagai bekal untuk melanjutkan pendidikan pada jenjang yang lebih tinggi serta mengembangkan ilmu pengetahuan dan teknologi [2]. Tentunya untuk memperoleh ketercapaian tujuan tersebut tidaklah mudah. Terlebih di masa pandemi seperti saat ini, pembelajaran langsung 
tidak terjadi, interaksi antara guru dan peserta didik kurang. Maka untuk mencapai tujuan tersebut, dibutuhkan sebuah pengembangan perangkat pembelajaran dengan model yang dapat menunjang kemandirian dan semangat belajar peserta didik sehingga tercipta pembelajaran yang lebih interaktif. Intisari dari kurikulum 2013 yaitu pelaksanaan pembelajaran di sekolah harus bersifat koopratif, yang mana semua pihak terlibat aktif selama pembelajaran. Peserta didik harus menunjukkan keaktifannya selama proses pembelajaran, sehingga pembelajaran yang berpusat kepada peserta didik dapat terwujud. Salah satu model pembelajaran yang dapat dikembangkan untuk memberikan keaktifan peserta didik selama pembelajaran adalah model reciprocal teaching atau pengajaran terbalik.

Reciprocal teaching adalah model yang berdasarkan prinsip-prinsip pengajuan pertanyaan yang mana keterampilan-keterampilan metakognitif diajarkan melalui pengajaran langsung dan pemodelan oleh guru [3]. Terdapat tiga aspek yang harus diperhatikan dalam penerapan model pembelajaran ini, yakni mengingat, berpikir dan memotivasi diri. Dalam model reciprocal teaching, guru mengajarkan peserta didik keterampilan-keterampilan kognitif dengan menciptakan pengalaman belajar, melalui pemodelan perilaku tertentu dan membantu peserta didik mengembangkan keterampilan tersebut atas usaha mereka sendiri dengan pembelajaran semangat, dukungan dan suatu sistem scaffolding [4]. Model ini, dapat mendorong peserta didik melaksanakan pembelajaran lebih aktif dan memahami isi dari bacaannya serta mendapatkan pengalaman belajar yang lebih bermakna untuk meningkatkan hasil belajar terutama di ranah kognitif. Model reciprocal teaching ini sangat tepat digunakan untuk pembelajaran fisika yang memiliki teori dan konsep abstrak serta perhitungan fisika. Dengan dikembangkannya perangkat pembelajaran model reciprocal teaching, diharapkan peserta didik menjadi lebih aktif. Sehingga tercipta pembelajaran yang lebih koopratif dan mampu membantu peserta didik mencari tahu atau mengeksplor kemampuannya untuk meningkatkan hasil belajar fisikanya. Akan tetapi, faktanya pembelajaran yang terjadi di sekolah tidak sesuai dengan tujuan kurikulum 2013. Hal tersebut terlihat dari observasi yang sudah dilakukan di sekolah.

Observasi dilakukan SMAN 1 Narmada kelas sepuluh dengan cara melakukan pengamatan langsung selama proses pembelajaran dikelas serta melakukan wawancara dengan guru pengampu. Pembelajaran yang berlangsung di sekolah masih dominan menggunakan model pembelajaran konvensional yang masih dibantu dengan media power point dan pembelajaran masih bersifat satu arah. Dalam kegiatan peembelajaran, guru hanya berperan sebagai penyampai informasi tanpa adanya interaksi antara guru dan peserta didik. Proses pembelajaran masih berpusat kepada guru (teacher centered) dan peserta didik kurang berperan aktif dalam pembelajaran. Sehingga pemahaman peserta didik akan materi hanya sebatas pada apa yang guru sampaikan dan pengalaman belajar yang diperoleh peserta didik tidak bermakna. Selain itu, salah satu permasalahan yang ditemukan adalah rendahnya hasil belajar fisika peserta didik dalam ranah kognitif. Peserta didik kesulitan dalam mencapai kompetensi dasar dan penguasaan materi yang telah ditentukan. Peserta didik mengalami kesulitan ketika sudah dihadapkan dengan perhitungan matematis.kemampuan analisis matematis yang kurang membuat peserta didik kesuliatan ketika menghadapi soal-soal yang berkaitan dengan fisika terutama di perhitungan fisika. Bukan hanya itu, peserta didik juga kesulitan dalam memahami konsep dan definisi dari besaran-besaran fisika. Hal tersebut didukung oleh data hasil penilaian akhir semester .

Berdasarkan observasi tersebut, terlihat bahwa peserta didik berperan sebagai penerima informasi saja tanpa ada keterlibatan aktif selama proses belajar. Diharapkan dengan pengembangan perangkat pembelajaran dengan model reciprocal teaching ini dapat memberikan sebuah inovasi bagi tenaga pendidik untuk diterapkan dalam proses pembelajaran di kelas sehingga dapat memberikan keaktifan peserta didik dalam melaksanakan proses pembelajaran dan diharapkan mampu memberikan perubahan terhadap hasil belajar fisika peserta didik.

\section{METODE PENELITIAN}

Penelitian ini menggunakan metode penelitian dan pengembangan atau Research and Development (R\&D) dengan Model penelitian yang akan digunakan adalah model 4D. Dimana model ini adalah model yang terdiri atas 4 tahap pengembangan yaitu: (1) Define; (2) Desain; (3) Develop dan; (4) Desseminate; [5]. Alur pelaksanaan penelitian dibuat dalam bentuk bagan berikut: 


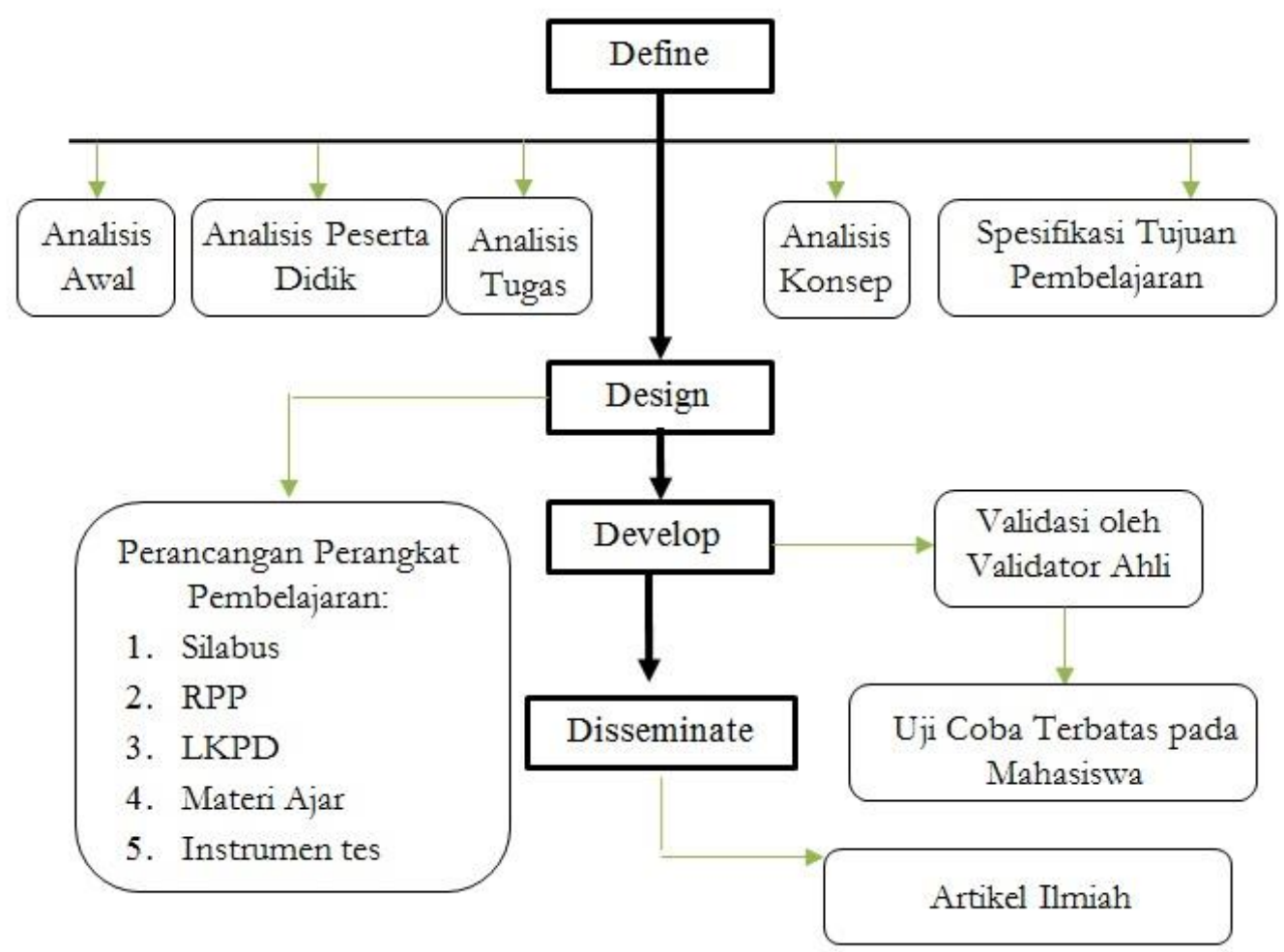

Gambar 1. Bagan Alur Pelaksanaan Pengembangan dengan Model 4D

Teknik pengumpulan data menggunakan lembar validasi dengan skala likert 1-4 yang akan dinilai oleh enam validator ahli yang terdiri dari tiga dosen dan tiga guru praktisi. Selanjutnya, dilakukan uji coba terbatas oleh mahasiswa pendidikan fisika dengan memberiksn angket respon untuk mengetahui tanggapan mahasiswa terhadap perangkat yang dikembangkan.

Analisis validitas perangkat pembelajaran dengan model reciprocal teaching dicari dengan menggunakan persamaan.

$$
\text { Nilai }=\frac{\text { Skor yang diperoleh }}{\text { N skor maksimum }} \times 100 \%
$$

Dengan skor penilaian intrumen dikonversi menjadi beberapa tingkat kelayakan pada tabel 1 sebagai berikut.

Tabel 1 Kriteria Validitas Perangkat Pembelajaran [6]

\begin{tabular}{cc}
\hline Skor & Kriteria \\
\hline $85,01-100,00 \%$ & Sangat valid \\
$70,01-85,00 \%$ & Cukup Valid \\
$50,01-70,00 \%$ & Kurang valid \\
$01,00-50,00 \%$ & Tidak valid \\
\hline
\end{tabular}

Analisis reliabilitas perangkat yang dikembangkan dengan data yang didapatkan dari angket yang diberikan kepada validator. Analisis reliabilitas menggunakan metode Borich yang dikenal dengan Percentage Agreement (PA) yaitu persentase kesepakatan antar penilai yang merupakan suatu persentase kesesuaian nilai antara penilai pertama dengan penilai kedua. Percentage Agreement (PA) dapat dirumuskan:

$$
\text { Percentage Agreement }(\mathrm{PA})=\left(1-\frac{A-B}{A+B}\right) \times 100 \%
$$


Instrumen dikatakan reliabel jika nilai presentase kesepakatannya lebih atau sama dengan $75 \%$. Jika dihasilkan kurang dari 75\%, maka harus diuji untuk kejelasan dan persetujuan dari pengamat [7].

Analisis respon mahasiswa dilakukan untuk mengetahui respon mahasiswa terhadap perangkat pembelajaran yang dikembangkan oleh peneliti. Peneliti menyebarkan angket ke 20 mahasiswa program studi pendidikan fisika melalui google form. Presentase respon dihitung dengan rumus:

$$
\text { presentase respon }=\frac{\text { jumlah yang memberikan respon positif }}{\text { jumlah yang mengisi angket }} \times 100 \%
$$

Kriteria hasil presentase yang diperoleh dapat dilihat pada tabel berikut 3.3

Tabel 2 Kategori Hasil Perhitungan Presentase Respon [8]

\begin{tabular}{ccc}
\hline Skor & Kategori \\
\hline $81 \%$ & $-100 \%$ & Sangat Baik \\
$61 \%$ & $-80 \%$ & Baik \\
$41 \%$ & $-60 \%$ & Cukup Baik \\
$21 \%$ & $-40 \%$ & Kurang Baik \\
$\leq 20 \%$ & Sangat Kurang Baik \\
\hline
\end{tabular}

\section{HASIL DAN PEMBAHASAN}

Penelitian ini merupakan penelitian pengembangan yang dilakukan untuk menghasilkan produk perangkat pembelajaran yang efektif. Perangkat pembelajaran merupakan suatu perencanaan yang dipergunakan dalam proses pembelajaran. Setiap guru pada satuan pendidikan berkewajiban menyusun perangkat pembelajaran yang lengkap, sistematis supaya pembelajaran dapat berlangsung secara interaktif, inspiratif, menyenangkan, menantang dan memotivasi peserta didik supaya berpartisipasi aktif [9]. Perangkat pembelajaran dengan model reciprocal teaching ini dikembangkan dengan materi momentum dan impuls yang diajarkan pada kelas sepuluh semester dua. Perangkat pembelajaran dengan model reciprocal teaching yang dikembangkan pada penelitian ini berupa silabus, RPP, LKPD, materi ajar dan instrumen tes hasil belajar peserta didik pada ranah kognitif. Perangkat pembelajaran dengan model reciprocal teaching ini akan memberikan kesempatan bagi peserta didik untuk lebih memahami pembelajaran yang dilakukan karena yang bertindak sebagai guru peserta didik itu sendiri.

Model reciprocal teaching adalah model pembelajaran yang memberikan kesempatan kepada peserta didik untuk belajar mandiri, kreatif dan lebih aktif, dimana peserta didik diberi kesempatan untuk mempelajari materi terlebih dahulu, kemudian peserta didik menjelaskan kembali materi yang dipelajari kepada peserta didik lainnya. Selanjutnya [1] berpendapat bahwa model reciprocal teaching merupakan strategi pembelajaran berdasarkan prinsp-prinsip pengajuan pertanyaan dimana peserta didik keterampilan-keterampilan metakognitif diajarkan melalui pengajaran langsung dan pemodelan oleh guru. Model reciprocal teaching ini juga memberikan kesempatan kepada peserta didik untuk menyampaikan informasi kepada peserta didik lainnya terkait dengan ringkasan yang telah dibuatnya [10]. penelitian Mochtar (2018) menunjukan bahwa model reciprocal teaching dapat memberikan perubahan positif terhadap hasil belajar fisika peserta didik [11].

Model reciprocal teaching merupakan teknik diskusi yang melibatkan empat strategi yang dilakukan dengan cara memprediksi (predict), mengklarifikasi (clariy), membuat pertanyaan (question) dan membuat ringkasan (summarize). langkah-langkah penerapan reciprocal teaching sebagai berikut: 1). Memberikan teks yang berkaitan dengan tema; 2). Memperkenalkan model reciprocal teaching ; 3). Memberikan pemodelan dari reciprocal teaching dan memotivasi peserta didik untuk menggunakannya; 4). Memantau peserta didik menggunakan model pembelajaran reciprocal teaching; 5). Menggunakan informasi yang diperoleh melalui pemantauan sebagai panduan untuk memotivasi peserta didik; [12].

Penyusunan instrumen tes hasil belajar ranah kognitif yang bersisi 25 soal pilihan ganda dan menggunakan indikator taksonomi bloom yakni C1-C6. Soal yang baik adalah soal yang tidak 
terlalu mudah dan soal yang tidak terlalu sukar [13]. Instrumen penelitian yang digunakan adalah angket validasi oleh ahli dan angket respon mahasiswa.

Perangkat yang dikembangkan divalidasi oleh 6 orang validator yaitu 3 dosen fisika dan 3 guru fisika. Validasi merupakan sebuah langkah unuk meyakinkan bahwa produk bersifat seperti semestinya. Tujuan dilakukannya validasi oleh validator adalah untuk memperoleh penilaian serta saran untuk perbaikan terkait perangkat yang dikembangkan [14]. Perangkat pembelajaran dikatakan valid apabila ada keterkaitan yang konsisten dari setiap komponen perangkat pembelajaran yang dikembangkan dengan karakteristik model dan atau pendekatan pembelajaran yang diterapkan [15]. Perhitungan validitas pada penelitian ini menggunkan presentase validitas. Hasil validasi perangkat dapat dilihat pada Tabel 3 dan tabel 4 .

Tabel 3. Rata-Rata Presentase Validasi dan Reliabilitas perangkat pembelajaran Oleh Ahli

\begin{tabular}{crrr}
\hline Perangat & Rata-rata validitas & Rata-rata Reliabilitas & Kategori \\
\hline Silabus & $84,38 \%$ & $91,81 \%$ & Cukup Valid/Reliabel \\
RPP & $79,17 \%$ & $94,88 \%$ & Cukup Valid/Reliabel \\
Materi Ajar & $84,17 \%$ & $95,71 \%$ & Cukup Valid/Reliabel \\
LKPD & $81,82 \%$ & $94,81 \%$ & Cukup Valid/Reliabel \\
Instrumen Tes & $85,00 \%$ & $93,81 \%$ & Cukup Valid/Reliabel \\
\hline
\end{tabular}

Tabel 4. Rata-Rata Presentase Validasi dan Reliabilitas perangkat pembelajaran Oleh Praktisi

\begin{tabular}{crrr}
\hline Perangat & Rata-rata validitas & Rata-rata Reliabilitas & Kategori \\
\hline Silabus & $88,54 \%$ & $91,81 \%$ & Sangat Valid/Reliabel \\
RPP & $93,06 \%$ & $94,88 \%$ & Sangat Valid/Reliabel \\
Materi Ajar & $91,67 \%$ & $95,71 \%$ & Sangat Valid/Reliabel \\
LKPD & $93,18 \%$ & $94,81 \%$ & Sangat Valid/Reliabel \\
Instrumen Tes & $90,83 \%$ & $93,81 \%$ & Sangat Valid/Reliabel \\
\hline
\end{tabular}

Berdasarkam tabel 3 dan tabel 4, dapat diketahui bahwa nilai rata-rata presentase validitas perangkat pembelajaran berada dalam kategori cukup valid serta reliabel yang didapatkan dari validator ahlli dan kategori sangat valid serta reliabel didapatkan dari validator pratisi. Nilai rata-rata presentase yang paling rendah diperoleh pada RPP dikarenakan tujuan pembelajaran belum memuat capaian pembelajaran dari yang tertinggi sampai yang terendeah dan penjabaran indikator pada RPP yang kurang spesifik dan alokasi waktu yang kurang sesuai dengan tahapan sintaks model pembelajaran. RPP yang baik penyusunanya akan memberikan dampak yang positif terhadap kesuksesan belajar peserta didik. Tujuan pembelajaran sangat menetukan keberhasilan suatu proses pembelajaran, karena tujuan pembelajaran berisi penguasaan kompetensi yang operasional ditargetkan dalam rencana pelaksanaan pembelajaran [16]. Berdasarkan penilaian oleh validator secara keseluruhan perangkat pembeljaran yang dikembangkan layak digunakan dalam proses pembelajaran dengan merevisi sesuai saran dari ahli. Perangkat pembelajaran layak digunakan berdasarkan hasil validasi perangkat pembelajaran tergolong dalam kriteria cukup valid [17].

Perangkat dengan model reciprocal teaching yang telah divalidasi mengalami revisi sesuai saran dan masukan dari validator ahli maupun praktisi. Saran digunakan sebagai dasar untuk menyempurnakan produk [18]. Perangkat yang telah melalui proses telaah atau validasi oleh ahli, direvisi, dan mendapatkan hasil minimal berkategori baik, maka perangkat dapat diimplementasikan dalam pembelajaran [19]. Adapun saran dan masukan dari validator terhadap perangkat yang dikembangkan antara lain menambahkan penjabaran indikator pencapaian kompetensi pada silabus, selannjutnya tujuan pembelajaran harus memuat capaian pembelajaran dari yang tertinggi sampai yang terendah serta alokasi waktu harus disesuaikan dengan tahapan sintaks, posisi gambar harus konsisten tidak berganti-ganti dan materi yang ditunjukkan harus baik serta tidak menghilangkan makna gambar, selanjutnya pada LKPD tidak ditemukan kegiatan praktiku dan tidak terdapat tabel yang harus diisi sebagai bahan diskusi peserta didik, serta pada instrumen tes belum ada kesesuaian soal dengan tujuan pembelajaran dari ranah yang tertinggi sampai yang terendah. Selanjutnya, dilakukan penyebaran angket pada mahasiswa sebagai data pendukung hasil validasi dari validator. Rata-rata respon dari mahasiswa pendidikan fisika yaitu 99,42\% yang berarti respon mereka sangat baik terhadap perangkat yang dikembangkan. Respon positif menunjukkan bahwa mahasiswa dapat 
menerima dengan baik perangkat pembelajaran yang dikembangkan dan tertarik apabila perangkat tersebut diterapkan dalam pembelajaran fisika [20].

Pengembangan model reciprocal teaching (pengajaran terbalik) sangat penting dikembangkan untuk memberikan fasilitas kepada peserta didik supaya lebih aktif selama proses pembelajaran. Peran aktif peserta didik dalam pembelajaran menggunakan model reciprocal teaching (pengajaran terbalik) tidak terlepas dari karena adanya kegiatan-kegiatan yang secara prinsip mengharuskan peserta didik untuk mengkonstruksi sendiri pengetahuannya. Reciprocal teaching (pengajaran terbalik) adalah pendekatan konstruktivis yang berdasarkan pada prinsip-prinsip pembuatan atau pengajuan pertanyaan [21]. Beberapa hasil penelitian sebelumnya diantaranya Nurwahidah \& Sarwi (2012), suniana \& agus wahyuni (2016), serta Rofi Afriani \& Fathiah Alatas (2017) telah melaporkan bahwa model pembelajaran dengan model reciprocal teaching pada pembelajaran fisika dapat meningkatkan hasil belajar fisika peserta didik serta dapat menjadikan peserta didik aktif selama proses pembelajaran berlangsung.

\section{KESIMPULAN}

Berdasarkan hasil penelitian yang telah dianalisis, dapat disimpulkan bahwa perangkat dengan model reciprocal teaching layak digunakan dalam pemeblajaran fisika dengan merevisi sesuai saran dan masukan dari validator ahli. Hal tersebut didasarkan dengan hasil perhitungan nilai presentase dalam kategori cukup valid. Perangkat pembelajaran yang dikembangkan diharapkan bisa menciptakan pembelajaran yang efektif dan efisien sehingga dapat membantu meningkatkan hasil belajar fisika, terkhusus pada materi momentum dan impuls. Untuk penelitian sejenis, diharapkan bisa dilakukan sampai tahap uji coba sehingga bisa mengetahui pengaruh model yang dikembangkan terhadap pebelajaran.

\section{UCAPAN TERIMA KASIH}

Puji syukur penulis ucapkaan kepada Allah Swt. yang telah memberikan nikmat sehat serta kesempatan sehingga penulis bisa menyelesaikan penulisan artikel ini. Selanjutnya Ucapan terima kasih yang sebesar-besarnya penulis ucapkan kepada kedua orang tua, dan semua pihak yang telah membantu dalam penulisan artikel ini, terkhusus untuk kedua pembimbing bapak Dr. Ahmad Harjono, S.Si., M.Pd. dan bapak Syahrial A., S.Pd., M.Si. yang telah meluangkan waktunya untuk membantu dari proses penelitian sampai penulisan artikel. Terakhir ucapan terima kasih penulis ucapkan untuk saudari Lisa Widiawati yang telah banyak membantu dalam meneyelesaikan penelitian ini.

\section{DAFTAR PUSTAKA}

[1] Huda, M. "Model-Model Pengajaran dan Pembelajaran: Isu-Isu Metodis \& Paradigmatis,". Yogyakarta: Pustaka Pelajar, 2014.

[2] Kemendikbud. "Permendikbud No. 103 tentang pedoman pelaksanaan pembelajaran,". Jakarta: Kemendikbud, 2014.

[3] Suyatno, S. “Menjelajah Pembelajaran Inovatif,”. Sidoarjo: Masmedia Buana Pustaka, 2009.

[4] Trianto, T. "Model Pembelajaran Inovatif Berorentasi Kontruktivistis,". Jakarta: Prestasi Pustaka, 2007.

[5] Thiagarajan, S., Semmel, D. S., \& Semmel, M. I. "Instructional Development for Training Teachers of Expotional Children,”. Indiana: Indiana University, 1974.

[6] Akbar, S. "Instrumen Perangkat Pembelajaran,”. Bandung: Remaja Rosdakarya, 2013.

[7] Borich, G. D. “Observation Skill for Effective Teaching,”. New York: Macmillan Publishing Company, 1994.

[8] Arikunto, S. "Prosedur Penelitian Suatu Pendekatan Praktik,". Jakarta: Rineka Cipta, 2010.

[9] Kunandar, K. "Penilaian Autentik,". Jakarta: Rajawali Pers, 2014. 
[10] Doolitle, D. "Model Reciprocal Teaching for Reading Comprehention in Higher Education : A Strategy for Fostering the Deeper Understanding of Texts," International Jurnal of Teaching and Learning in Higher Education, vol. 17, no. 2, pp. 106-118, 2006.

[11] Mochtar, P. N., \& Suyoso, S. "Pengaruh Penggunaan Model Reciprocal Teaching pada Pembelajaran Fisika Terhadap Peningkatan Motivasi dan Hasil Belajar," Jurnal Pendidikan Matematika dan Sains, vol. 2, no. 1, pp. 1-8, 2018.

[12] Oczuks, L. "Reciprocal teaching at work: Strategies for improving reading comprehension," Newark, DE: International Reading Association Jurnal, 2003.

[13] Arikunto, S. “Prosedur Penelitian: Suatu Pendekatan Praktik,”. Jakarta : Rineka Cipta, 2016.

[14] Wijayanti, W., Maharta, N., \& Suana. W. "Pengembangan Perangkat Blended Learning Berbasis Learning Management System pada Materi Listrik Dinamis," Jurnal Ilmiah Pendidikan Fisika, vol. 6 no. 1, pp. 1-12, 2017.

[15] Asikin, M \& Cahyono, A. N. "Penelitian Pengembangan Dalam Bidang Pendidikan," Makalah disajikan di Sekolah Riset FMIP A UNNES, 2000.

[16] Sahidu, C. "Pengembangan Program Pembelajaran Fisika,". Mataram: FKIP UNRAM, 2016.

[17] Fatmawati, A. "Pengembangan Perangkat Pembelajaran Konsep Pencemaran Lingkungan menggunakan Model Pembelajaran Berdasarkan Masalah untuk SMA Kelas X," Jurnal EduSains, vol. 4, no. 2, pp. 94-103, 2016.

[18] Nisyah, M., Gunawan, G., Harjono, A., \& Kusdiastuti, M. "Perangkat Pembelajaran Model Inkuiri Dipadu Advance Organizer untuk Meningkatkan Penguasaan Konsep dan Kemampuan Pemecahan Masalah Fisika Siswa," Jurnal Pijar MIPA. Vol. xx, no. x, pp. 1-6, 2019.

[19] Rahmawati, F., Soegimin, S., \& Kardi, S. "Pengembangan Perangkat Pembelajaran Fisika Model Inkuiri Terbimbing Berbantuan Videoscribe pada Materi Kalor untuk Meningkatkan Hasil Belajar Siswa SMAN 1 Kedungwaru," Jumal Penelitian Pendidikan Sains, Vol. 5, no. 2, pp. 1039-1047, 2016.

[20] Sulardi, S., Nur, M., \& Widodo, W. "Pengembangan Perangkat Pembelajaran Fisika Model Problem Based Learning (PBL) untuk Melatih Keterampilan Berpikir Kritis Siswa," Jurnal Penelitian Pendidikan Sains, vol. 5 , no. 1, pp. 802-810, 2015.

[21] Trianto, T. "Model Pembelajaran Inovatif Berorentasi Kontruktivistis,". Jakarta: Prestasi Pustaka, 2007.

[22] Nurwahidah, I., Sarwi, S., \& Handayani, L. "Penerapan Model Pembelajaran Reciprocal Teaching Berbasis Koopratif untuk Meningkatkan Pemahaman Konsep Fisika Siswa Kelas X," Unnes Physics Education Journal, vol. 1, no. 2, pp. 54-59, 2012.

[23] Rofi, A., Fathiah, A., \& Hasian, P. "Penerapan Model Reciprocal Teaching Terhadap Hasil Belajar Dan Kemampuan Berkomunikasi Siswa Pada Konsep Fluida Statis," Prosiding Seminar Nasional Pendidikan FKIP UNTIRTA, 2017.

[24] Suniana, S., Agus, W., \& Yuzrizal, Y. "Penerapan Pendekatan Pengajaran Terbalik (Reciprocal Teaching) Untuk Meningkatkan Hasil Belajar Fisika Siswa Pada Materi Fluida Statis Di Kelas Xi-Ipa 1 Sma Negeri 1 Bubon," Jurnal Ilmiah Mahasiswa (JIM) Pendidikan Fisika, vol. 1, no. 2, pp. 151-160, 2016. 